\title{
SCREENING OF FUNGAL ENDOPHYTES FOR THEIR BIOCONTROL POTENTIAL AGAINST Rhizopus sp. ISOLATED FROM DISEASED CASSAVA (Manihot esculenta Crantz)
}

\section{Onyemaechi Henry Obiazikwor*, Obehi Vera Ofeimu and Felix Onome}

\author{
Department of Plant Biology and Biotechnology, Faculty of Life Sciences, University of \\ Benin, Benin City, Nigeria \\ *Correspondent Author Email: onyemaechi.obiazikwor@uniben.edu \\ *Phone number: +2348136440596
}

Cite this article:

Onyemaechi H.O., Obehi V.O., Felix O. (2021), Screening of Fungal Endophytes for their Biocontrol Potential against Rhizopus sp. Isolated from Diseased Cassava (Manihot esculenta Crantz). African Journal of Biology and

Medical Research 4(2), 25-37. DOI:10.52589/AJBMR/DVES YIRZ.

\section{Manuscript History}

Received: 7 July 2020

Accepted: 31 Aug 2020

Published: 22 April 2021

Copyright $\odot 2020$ The Author(s). This is an Open Access article distributed under the terms of Creative Commons Attribution-

NonCommercial-

NoDerivatives 4.0 International (CC BY-NC-ND 4.0 ), which permits anyone to share, use, reproduce and redistribute in any medium, provided the original author and source are credited.
ABSTRACT: The aim of this study was to screen for the biocontrol potential of fungal endophytes isolated from cassava against a test pathogen of cassava. Fungal endophytes and pathogen were isolated and identified from healthy and diseased cassava respectively. The isolated fungal endophytes were screened for their biocontrol potential against a test pathogen using the dual culture and culture filtrate assay. Fusarium sp., Botryosphaeria sp., Colletotrichum sp., yeast isolate 1 and 2 were the isolated fungal endophytes while the pathogen was Rhizopus sp. The effect of endophytes on the mycelia growth of Rhizopus sp. using the dual culture assay indicated that yeast isolate $1 \& 2$ and Colletotrichum sp. were effective in inhibiting the mycelia growth of the test pathogen while Fusarium sp. and Botryosphaeria sp. were not effective. The co-culture of yeast isolate 2 with the test pathogen gave the lowest mycelia growth $\left(1.66^{a} \pm 0.09\right)$ at day 2. The effect of endophytic culture filtrate on the mycelia growth of Rhizopus sp. showed that Fusarium sp. gave the lowest mycelia growth in the three days observed. The findings from this study suggested that the test endophytes have biocontrol potential against Rhizopus sp. The biocontrol abilities of the test endophytes vary using the dual culture and culture filtrate assay.

KEYWORDS: Bio-Control, Dual Culture, Culture Filtrate, Endophytes, Screening, Rhizopus Sp. 


\section{INTRODUCTION}

Cassava which is one of the major food crops in Africa is well known for its high richness in carbohydrate (starch), as well as other nutrients such as vitamin, magnesium, potassium and proteins (Desse and Taye, 2001). It is very popular and widely used in various parts of the word (Alves, 2002). Cassava is consumed by a large proportion of the world's population. Various kinds of food or food supplements that can be derived from cassava include: cassava flour, tapioca, abacha and fufu (IITA, 1990). Apart from being used as food, cassava can also be used for other purposes such as production of enzymes and fermentation processes in industries, medicine, ornamentals and livestock feed (Ceballos 2012; Moore, 2005).

In the cultivation of cassava, farmers are faced with many challenges such as weeds, pests, diseases, soil and agronomic factors which cause reduction in yield (IITA, 1990). Several control measures have been used for the management of plant diseases. They include: chemical, physical, cultural and biological methods (Agrios, 2005). Chemical method seems to be the most commonly practiced but it has several limitations. For instance; the use of chemicals may increase microbial resistance and health hazards. Therefore, biological method is the most preferable because it is environmentally friendly and it is cheap. The use of endophytes as biological agents is gaining importance in this regard.

An endophyte is a micro-organism, mainly fungus or bacterium, which lives within plant tissues without causing any harm to its host (Gao et al., 2010). They are involved in a mutualistic-symbiotic association with plants. They confer protection to plants and increase plant growth and productivity. The plant in return provides food and habitat for the endophytes (Gao et al., 2010; Stone et al., 2000). They have been referred to as hidden protective associates of plants (Okungbowa et al., 2019). Endophytes are very good biological agents use in controlling plant diseases. In biocontrol, endophytes are preferably used because they have various mechanisms which they use to suppress pathogens and they do not cause any harm to the plant. These mechanisms used by endophytes to suppress pathogens could either be direct or indirect. The direct mechanisms include: competition, antibiotic-mediated suppression, parasitism and predation, cell wall degradation and lysis. Indirect mechanism includes induced resistance (Gao et al., 2010).

In this study, some fungal endophytes isolated from healthy cassava were screened for their biocontrol potential against Rhizopus sp. isolated from diseased cassava.

\section{MATERIALS AND METHODS}

Materials used: Conical flask, petri dishes, McCartney bottles, beaker, measuring cylinder, cork-borer, inoculation loop, syringe, micro-pipette, scale, test-tube, Bunsen burner and meter rule.

Experimental procedures: the experiment was carried out by following the following procedures

Collection of plant samples: Healthy leaves, stems and roots and diseased leaves of cassava were collected from a cassava farm located at staff quarters, university of Benin, Benin City, Edo state, Nigeria. 
Preparation of samples: Plant sample preparation for the isolation of fungal endophytes was carried out following the modified method of Katoch and Pull, 2017. The healthy plant parts were washed with clean water and surfaced sterilize with alcohol (70\% ethanol) to avoid surface contamination. The samples were teased into small bits and soaked in sodium hypochloride for three minutes, rinsed with distilled water for three times. Plant sample preparation for the isolation of fungal pathogen was carried out according to the modified method of Obiazikwor and Shittu, 2018. The diseased leaf samples were prepared by washing and surface sterilization using $70 \%$ ethanol. The infected parts of the leaves were then teased out using sterile scalpel and rinsed with sterile distilled water.

Preparation and sterilization of medium: The medium used was Potato Dextrose Agar (PDA) and it was prepared according to the manufacturer's instructions. In preparing the medium, 39g of PDA powder was dissolved in 1 litre of distilled water. The medium was sterilized using autoclave for 15 minutes at $121{ }^{\circ} \mathrm{C}$. The medium was aseptically dispensed into petri dishes after it was left to cool down. Two hundred and fifty milligram $(250 \mathrm{mg})$ of chloramphenicol was added to $250 \mathrm{ml}$ of the medium before pouring to inhibit bacteria growth

Isolation of fungal endophytes and pathogen: This was carried out using direct plating method. After the medium solidified, the prepared plant samples were inoculated in the correct labelled plates. Five (5) $\mathrm{ml}$ of the water used for the last wash was also plated out to serve as negative control in the isolation of endophyte. Cultures were incubated at room temperature $\left(28 \pm 2{ }^{\circ} \mathrm{C}\right)$ for 72 hours.

Sub-culturing of fungal endophytes and pathogen: Sub-culturing was carried out to obtain pure cultures. The mycelia of the fungi culture were picked up using a sterilized inoculation loop and were inoculated into a fresh potato dextrose agar medium. The cultures were incubated at room temperature $\left(28 \pm 2^{\circ} \mathrm{C}\right)$ for 72 hours.

Description and identification of fungal isolates: The identification of the fungal isolates was done using macroscopy and microscopy. For the macroscopy, the morphological characteristics of the fungal isolates were described. For the microscopy, the fungal isolates were stained with lactophenol blue dye on clean and sterilized glass slide. The mycelia were teased to have a homogenous mixture. The mixture was gently covered with cover slips and allowed to stay for few seconds. The slide was viewed under the microscope at $\mathrm{x} 40$ magnification. This was then compared with a laboratory manual for fungal identification.

Determination of biocontrol potential of fungal endophytes against the test pathogen: This was carried out using the dual and culture filtrate assay as described by Katoch and Pull, 2017.

a) Dual culture assay: Each of the test endophyte was co-cultured with the test pathogen on PDA medium. Culture plug of the endophyte and pathogen were co-cultured at the two opposite ends of the plates. The plates were incubated at room temperature after sealing them with parafilm. The pathogens alone (at one end of plate) without endophyte served as control. The diameter of the cork borer used was $5 \mathrm{~mm}$. The mycelia growth of the pathogen was measured at 24 hours interval. Percentage antagonism was calculated as described by Katoch and Pull, 2017. 
Percentage antagonism $=\frac{\mathrm{P}-\mathrm{E}}{\mathrm{P}} \times \frac{100}{1}$

Where; $\mathrm{E}=$ average mycelia measurement of endophyte

$\mathrm{P}=$ Average mycelia measurement of control

\section{b) Culture filtrate assay:}

Broth culture was prepared by dissolving $10 \mathrm{~g}$ of glucose in $250 \mathrm{ml}$ of distilled water. An aliquot of $50 \mathrm{ml}$ of the broth was dispensed into five McCartney bottles labelled E1 to E5 and sterilized for 15 minutes using an autoclave. Each endophyte was inoculated to the labeled bottle containing the broth after cooling. This was carried out using a sterile cork borer (5 $\mathrm{mm}$ ) to create culture plugs on the pure cultures of the endophyes. A syringe was used to pick it and inoculate each in the already prepared broth respectively. Broth cultures of endophytes were incubated at room temperature $\left(28 \pm 2{ }^{\circ} \mathrm{C}\right)$ for 14 days (Plate 1)

After incubation of the culture for 14 days, the culture filtrate was prepared as follow: The broth culture was shaken to have a homogenous mixture. Ten (10) $\mathrm{ml}$ of the broth culture was poured into a clean and sterile test-tube and centrifuged. Centrifugation was done for 30 minutes at 3000 revolutions per minutes (rpm). After centrifuging, the top clear layer of the broth culture was decanted and filtered using a Whatman filter paper into another sterile testtube. Two hundred (200) $\mu \mathrm{l}$ of the filtrate was measured using a micro-pipette and dispensed into sterile petri dish. Already prepared and sterilized potato dextrose agar was aseptically dispensed into the petri dishes containing the filtrate, shaken gently and allowed to solidify. After the medium gelled, the pathogen was inoculated at the centre of the petri dish and incubated at room temperature (28 \pm 2 ). Pathogen inoculated on PDA without culture filtrate served as the control. Mycelia growth measurement was taken 24 hours interval.

\section{Preliminary study to investigate mechanisms of action of the test endophytes}

The endophytes were cultured with pathogen and singly. The method of inoculation used was as described in the dual culture assay. The mycelia growth of endophytes in single and culture with pathogen was observed. Proper comparison was done to suggest possible mechanisms of action of the test fungal endophytes. 


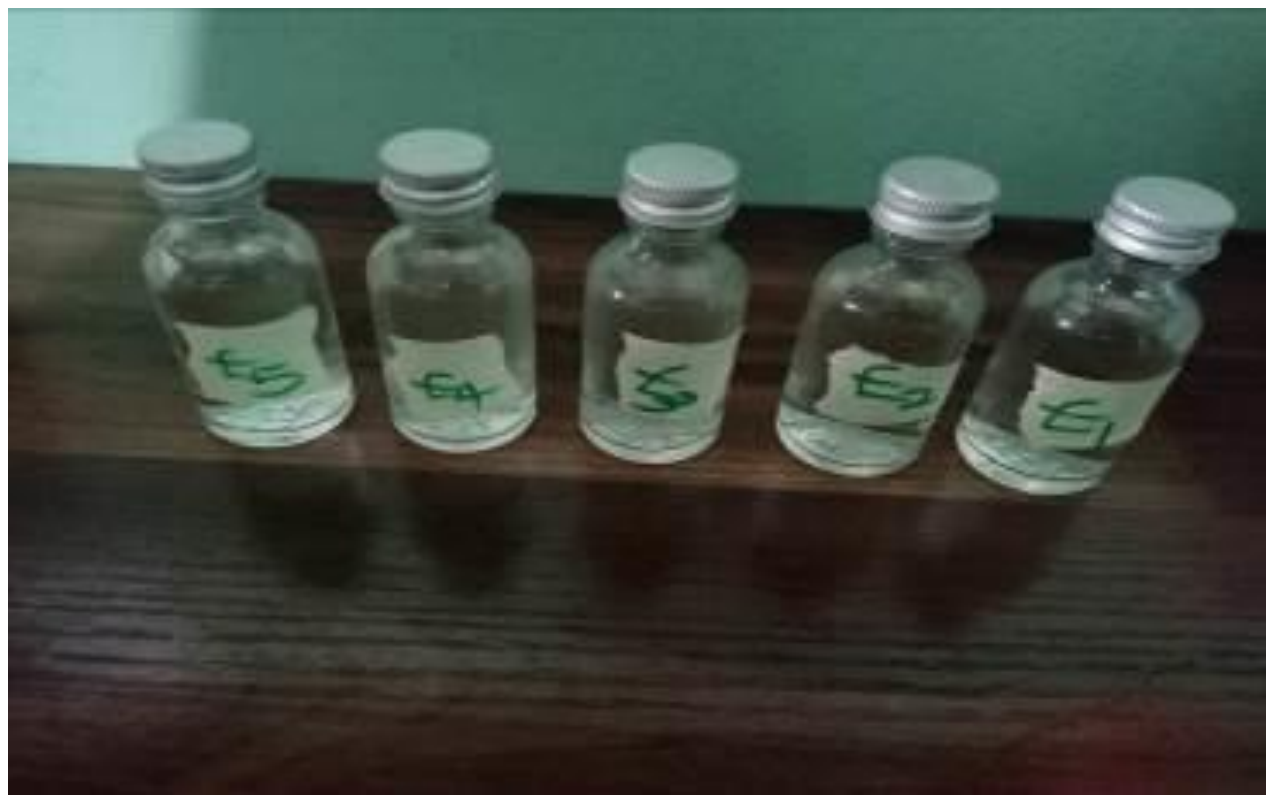

Plate 1: Broth cultures of endophytes

Statistical analysis: Each treatment was in three replicates and results were presented as mean \pm standard error. The data obtained were subjected to parametric and descriptive statistics using the Statistical Package for the Social Sciences (SPSS), version 20 software. An alpha value of 0.05 was used as the level of significance and post hoc analysis was carried using the Duncan multiple range test.

\section{RESULTS}

In this study, the five endophytes isolated from healthy cassava plant. They were coded as E1, E2, E3, E4 and E5 and identified to be Fusarium sp., Botryosphaeria sp., yeast isolate 1, yeast isolate 2 and Colletotrichum sp. respectively (Table 1, Plate 2). Plate 3 showed the pure of culture of the test pathogen, Rhizopus sp. isolated from diseased cassava.

Table 1: Morphological description of fungal endophytes isolated from healthy cassava

\begin{tabular}{|c|c|c|c|c|c|c|c|}
\hline \multirow[t]{2}{*}{ Endophyte } & \multirow[t]{2}{*}{ Source } & \multicolumn{6}{|c|}{ Morphology } \\
\hline & & Margin & Elevation & Size & Texture & Pigmentation & $\begin{array}{l}\text { Optical } \\
\text { property }\end{array}$ \\
\hline E1 & Root & Entire & Raised & Small & Rough & Off white & Opaque \\
\hline $\mathrm{E} 2$ & Young leave & Rough & Raised & Large & Rough & Off white & Opaque \\
\hline E3 & Root & Rough & Not raised & Large & Smooth & White & Opaque \\
\hline E4 & Stem & Rough & Not raised & Large & Smooth & White & $\begin{array}{l}\text { Opaque } \\
\text { Slightly }\end{array}$ \\
\hline E5 & Matured leave & Rough & Raised & Large & Rough & White & transparent \\
\hline
\end{tabular}

Legend: E1= Fusarium sp., E2= Botryosphaeria sp., E3= Yeast isolate 1, E4= Yeast isolate 2 and E5= Colletotrichum sp. 


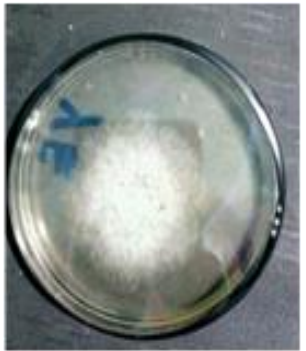

E1

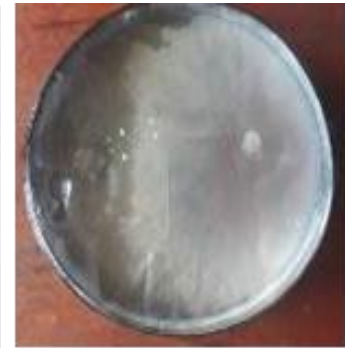

E2

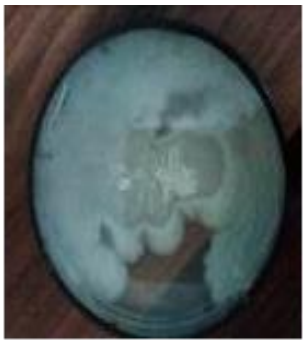

E3

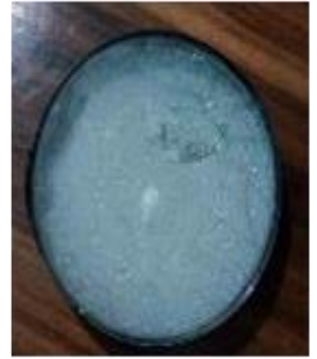

E4

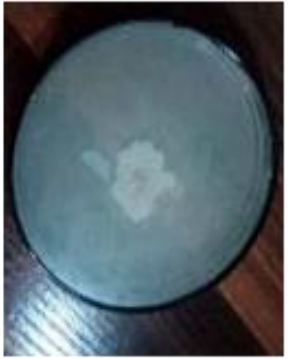

E5

Plate 2: Pure cultures of isolated fungal endophytes grown on PDA after 48 hours of incubation at room temperature $\left(28 \pm 2^{\circ} \mathrm{C}\right)$

Legend: E1= Fusarium sp., E2= Botryosphaeria sp., E3= Yeast isolate 1, E4= Yeast isolate 2 and E5= Colletotrichum sp.

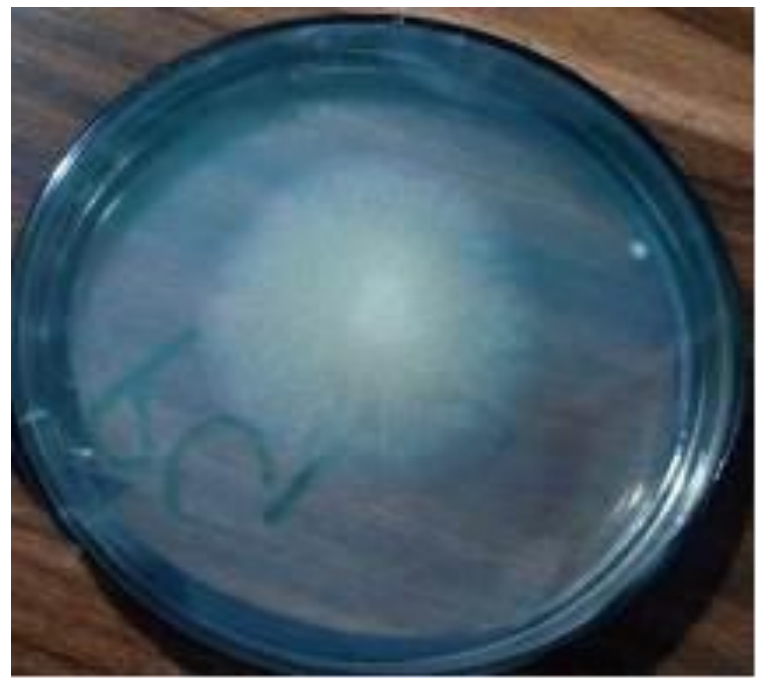

Plate 3: Pure culture of Rhizopus sp. isolated from diseased cassava after two days of culture on PDA at room temperature $\left(28 \pm 2{ }^{\circ} \mathrm{C}\right)$

The effect of endophytes on the mycelia growth of Rhizopus sp. using the dual culture assay (Table 2) indicated that there were no significant differences in the mycelia growth of the test pathogen in single and co-culture with Botryosphaeria and Collectotrichum spp. at day 1 which is after 24 hours. At day 2, there were significant differences observed in the mycelia growth of Rhizopus sp. in single and co-culture with Yeast isolate1 and 2 respectively. 
Table 2: Effect of endophytes on the mycelia growth of Rhizopus sp. using the dual culture assay

\begin{tabular}{lccc}
\hline Treatments & \multicolumn{3}{c}{ Mycelia Growth Measurements $(\mathbf{c m})$} \\
& Day 1 & Day2 & Day3 \\
\hline Control & $3.33^{\mathrm{b}} \pm 0.13$ & $5.05^{\mathrm{bc}} \pm 0.46$ & $5.58^{\mathrm{c}} \pm 0.63$ \\
E1+P & $5.67^{\mathrm{c}} \pm 0.93$ & $5.93^{\mathrm{c}} \pm 0.93$ & $6.80^{\mathrm{c}} \pm 0.10$ \\
$\mathrm{E} 2+\mathrm{P}$ & $3.88^{\mathrm{b}} \pm 0.18$ & $5.95^{\mathrm{bc}} \pm 0.10$ & $5.96^{\mathrm{c}} \pm 0.28$ \\
$\mathrm{E} 3+\mathrm{P}$ & $1.58^{\mathrm{a}} \pm 0.18$ & $1.97^{\mathrm{a}} \pm 0.03$ & $2.38^{\mathrm{a}} \pm 0.73$ \\
E4+P & $1.38^{\mathrm{a}} \pm 0.18$ & $1.66^{\mathrm{a}} \pm 0.09$ & $2.38^{\mathrm{a}} \pm 0.23$ \\
E5+P & $3.37^{\mathrm{b}} \pm 0.03$ & $3.75^{\mathrm{b}} \pm 0.10$ & $3.98^{\mathrm{b}} \pm 0.33$ \\
\hline
\end{tabular}

Values are presented as means \pm standard error; Figures bearing similar superscripts within columns are not significantly different using Duncan's Multiple Range (DMR) test at 0.05 level of significance Legend: Control $=$ Rhizopus sp. in single culture, $\mathrm{E} 1+\mathrm{P}=$ Fusarium sp. + Rhizopus sp., $\mathrm{E} 2+\mathrm{P}=$ Botryosphaeria sp. + Rhizopus sp., $\mathrm{E} 3+\mathrm{P}=$ Yeast isolate $1+$ Rhizopus sp., $\mathrm{E} 4+\mathrm{P}=$ Yeast isolate $2+$ Rhizopus sp., E5+P = Collectotrichum sp. + Rhizopus sp.

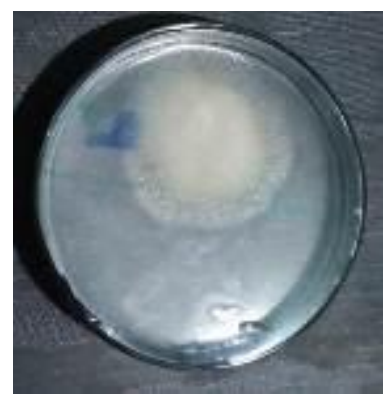

$\mathrm{P}$

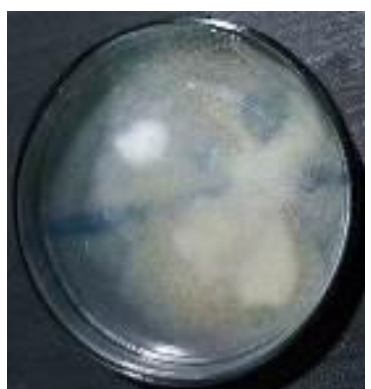

$\mathrm{E} 1+\mathrm{P}$

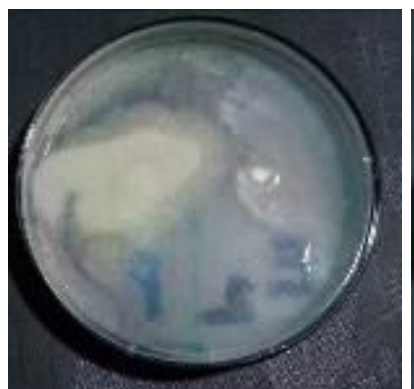

$\mathrm{E} 2+\mathrm{P}$

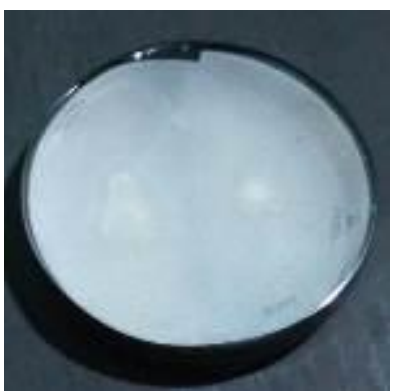

$\mathrm{E} 3+\mathrm{P}$

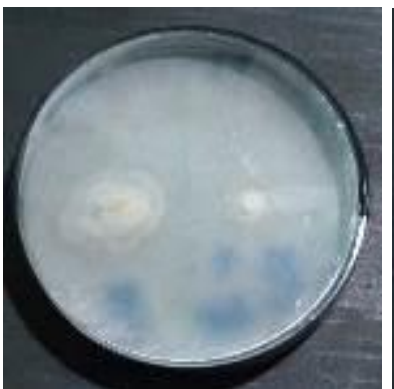

$\mathrm{E} 4+\mathrm{P}$

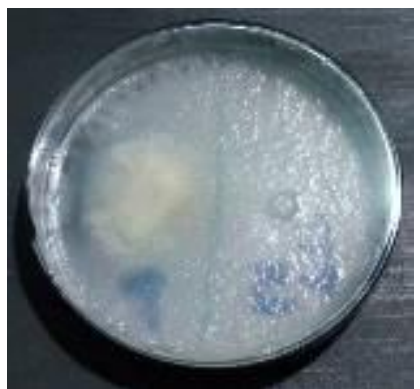

$\mathrm{E} 5+\mathrm{P}$

Plate 4: Dual culture of fungal endophytes with Rhizopus sp. on PDA at day 2 (after 48 hours of incubation)

Legend: Control $=$ Rhizopus $\mathrm{sp}$. in single culture, $\mathrm{E} 1+\mathrm{P}=$ Fusarium $\mathrm{sp} .+$ Rhizopus sp., $\mathrm{E} 2+\mathrm{P}=$ Botryosphaeria sp. + Rhizopus sp., $\mathrm{E} 3+\mathrm{P}=$ Yeast isolate $1+$ Rhizopus sp., $\mathrm{E} 4+\mathrm{P}=$ Yeast isolate $2+$ Rhizopus sp., E5+P = Collectotrichum sp. + Rhizopus sp.

Table 3 shows the bio-control potential of the test endophytes against Rhizopus sp. using the dual culture assay in terms of percent growth antagonism. No inhibition against the test pathogen was observed for Fusarium sp. for the three days observed. The highest percentage antagonism $(66.80 \%)$ was recorded at day two for yeast isolate 2 . 
Table 3: Biocontrol potential of endophytes against Rhizopus sp. using the dual culture assay in terms of percent growth antagonism

\begin{tabular}{cccc} 
& \multicolumn{2}{c}{ PERCENTAGE ANTAGONISM (\%) } \\
& DAY 1 & \multicolumn{2}{c}{ DAY 2 } \\
ENDOPHYTES & DAY 3 & - & - \\
\hline E 1 & - & - & - \\
E 2 & - & $\mathbf{6 0 . 5 0}$ & $\mathbf{5 0 . 2 7}$ \\
E3 & $\mathbf{5 2 . 4 5}$ & $\mathbf{6 6 . 8 0}$ & $\mathbf{5 7 . 4 4}$ \\
E4 & $\mathbf{6 0 . 7 1}$ & 25.00 & 28.77 \\
\hline
\end{tabular}

Legend: E1= Fusarium sp., E2= Botryosphaeria sp., E3= Yeast isolate 1, E4= Yeast isolate 2 and $\mathrm{E} 5=$ Colletotrichum $\mathrm{sp} . \mathbf{2 5 0}$ inhibitions are in bold

The effect of endophytic culture filtrate on the mycelia growth of Rhizopus sp. is shown in Table 4. At day 1, there was no significant difference between the mycelia growth of Rhizopus sp. $\left(1.85^{\mathrm{ab}} \pm 0.10\right.$ and $\left.1.95^{\mathrm{ab}} \pm 0.15\right)$ treated with the culture filtrates of yeast isolate 1 and 2 respectively. At day3, Rhizopus sp. treated with the culture filtrate of Fusarium sp. gave the lowest mycelia growth $\left(1.67^{\mathrm{a}} \pm 0.40\right)$.

Table 4: Effect of endophytic culture filtrate on the mycelia growth of Rhizopus sp.

\begin{tabular}{lccc}
\hline Treatments & \multicolumn{3}{c}{ Mycelia Growth Measurements (cm) } \\
& Day 1 & Day2 & Day3 \\
\hline Control & $2.18^{\mathrm{bc}} \pm 0.25$ & $4.48^{\mathrm{c}} \pm 0.28$ & $5.95^{\mathrm{c}} \pm 0.35$ \\
CF of E1 & $1.65^{\mathrm{a}} \pm 0.00$ & $1.66^{\mathrm{c}} \pm 0.50$ & $1.67^{\mathrm{a}} \pm 0.40$ \\
CF of E2 & $2.63^{\mathrm{c}} \pm 0.23$ & $2.83^{\mathrm{ab}} \pm 0.68$ & $2.84^{\mathrm{ab}} \pm 0.28$ \\
CF of E3 & $1.85^{\mathrm{ab}} \pm 0.10$ & $1.90^{\mathrm{a}} \pm 0.15$ & $2.08^{\mathrm{ab}} \pm 0.03$ \\
CF of E4 & $1.95^{\mathrm{ab}} \pm 0.15$ & $2.20^{\mathrm{bc}} \pm 0.15$ & $2.38^{\mathrm{a}} \pm 0.23$ \\
CF of E5 & $2.20^{\mathrm{bc}} \pm 0.15$ & $3.25^{\mathrm{bc}} \pm 0.00$ & $3.98^{\mathrm{b}} \pm 0.45$ \\
\hline
\end{tabular}

Values are presented as means \pm standard error; Figures bearing similar superscripts within columns are not significantly different using Duncan's Multiple Range (DMR) test at 0.05 level of significance

Legend: Control $=$ Rhizopus sp. without any treatment, $\mathrm{CF}=$ Culture filtrate, $\mathrm{E} 1=$ Fusarium sp., $\mathrm{E} 2=$ Botryosphaeria $\mathrm{sp} ., \mathrm{E} 3=$ Yeast isolate 1, E4= Yeast isolate 2 and E5= Colletotrichum $\mathrm{sp}$.

The biocontrol potential of endophytes against Rhizopus sp. using culture filtrate assay in terms of percentage antagonism (Table 5) indicated that Botryosphaeria and Collectotrichum spp. showed no inhibition at day 1. The highest percentage growth antagonism (72.27) was recorded for Fusarium sp. at day 3 while the least was recorded for yeast isolate 2 at day 1 . 
Table 5: Biocontrol potential of endophytes against Rhizopus sp. using the culture filtrate assay in terms of percent growth antagonism

\begin{tabular}{cccc}
\hline & \multicolumn{4}{c}{ PERCENTAGE ANTAGONISM (\%) } \\
ENDOPHYTES & DAY 1 & DAY 2 & DAY 3 \\
\hline E 1 & 24.31 & $\mathbf{6 6 . 5 2}$ & $\mathbf{7 2 . 2 7}$ \\
E 2 & - & 36.95 & $\mathbf{5 3 . 3 7}$ \\
E3 & 15.14 & $\mathbf{5 7 . 5 9}$ & $\mathbf{6 5 . 1 3}$ \\
E4 & 10.55 & $\mathbf{6 1 . 1 6}$ & $\mathbf{6 5 . 5 5}$ \\
E5 & - & 27.46 & 45.38 \\
\hline
\end{tabular}

Legend: E1= Fusarium sp., E2= Botryosphaeria sp., E3= Yeast isolate 1, E4= Yeast isolate 2 and $\mathrm{E} 5=$ Colletotrichum $\mathrm{sp} . \mathbf{2 5 0}$ inhibition is in bold

Table 6 shows the mycelia growth of test endophytes in single culture and in dual culture with Rhizopus sp. there was no significant difference in the mycelia growth of yeast isolate 2 in single and dual culture with Rhizopus sp. for the three days observed. Significant differences were observed in the mycelia growth of the other test endophytes in single and co-culture with Rhizopus sp. for the three days observed.

Table 6: Mycelia growth of test endophytes in single and co-culture with Rhizopus sp.

\begin{tabular}{|c|c|c|c|c|}
\hline \multirow[t]{2}{*}{$\begin{array}{l}\text { Culture } \\
\text { type }\end{array}$} & \multirow[b]{2}{*}{ Endophyte } & \multicolumn{3}{|c|}{ Mycelia growth measurements $(\mathrm{cm})$} \\
\hline & & Day1 & Day2 & Day3 \\
\hline Single & E1 & $4.50^{c} \pm 0.10$ & $4.95^{\mathrm{b}} \pm 0.05$ & $4.95^{\mathrm{b}} \pm 0.05$ \\
\hline Dual & E1 & $0.75^{\mathrm{a}} \pm 0.05$ & $1.03^{\mathrm{a}} \pm 0.03$ & $1.35^{\mathrm{a}} \pm 0.05$ \\
\hline Single & E2 & $7.50^{f} \pm 0.10$ & $8.30^{\mathrm{g}} \pm 0.00$ & $8.30^{\mathrm{g}} \pm 0.00$ \\
\hline Dual & E2 & $3.33^{\mathrm{b}} \pm 0.03$ & $3.73^{\mathrm{b}} \pm 0.03$ & $3.93^{\mathrm{b}} \pm 0.03$ \\
\hline Single & E3 & $8.30^{\mathrm{g}} \pm 0.00$ & $8.30^{\mathrm{g}} \pm 0.00$ & $8.30^{\mathrm{g}} \pm 0.00$ \\
\hline Dual & E3 & $5.28^{\mathrm{d}} \pm 0.08$ & $5.45^{\mathrm{e}} \pm 0.10$ & $5.77^{\mathrm{d}} \pm 0.02$ \\
\hline Single & E4 & $8.30^{\mathrm{g}} \pm 0.00$ & $8.30^{\mathrm{g}} \pm 0.00$ & $8.30^{\mathrm{g}} \pm 0.00$ \\
\hline Dual & $\mathrm{E} 4$ & $8.30^{\mathrm{g}} \pm 0.00$ & $8.30^{\mathrm{g}} \pm 0.00$ & $8.30^{\mathrm{g}} \pm 0.00$ \\
\hline Single & E5 & $8.30^{\mathrm{g}} \pm 0.00$ & $8.30^{\mathrm{g}} \pm 0.00$ & $8.30^{\mathrm{g}} \pm 0.00$ \\
\hline Dual & E5 & $6.25^{\mathrm{e}} \pm 0.05$ & $6.55^{\mathrm{f}} \pm 0.07$ & $6.55^{\mathrm{f}} \pm 0.05$ \\
\hline
\end{tabular}

Values are presented as means \pm standard error; Figures bearing similar superscripts within columns are not significantly different using Duncan's Multiple Range (DMR) test at 0.05 level of significance

Legend: $\mathrm{E} 1=$ Fusarium sp., E2= Botryosphaeria sp., E3= Yeast isolate 1, E4= Yeast isolate 2 and $\mathrm{E} 5=$ Colletotrichum sp. 


\section{DISCUSSION}

In this study, the five endophytes isolated from healthy cassava plant were coded as E1, E2, E3, E4 and E5 and they were identified to be Fusarium sp., Botryosphaeria sp., yeast isolate 1, yeast isolate 2 and Colletotrichum sp. respectively (Table 1). Fusarium sp. belongs to the group of soil borne microflora which is known to cause wilts and root rots in plants, however, some species are non-pathogenic and are good bio-control agents (Kaur et al., 2010). Yeast is known to cause diseases in both plants and animals. In animals it causes candidiasis and rashes, while in plants, it causes molds and rot diseases (Schisler et al., 2011). Endophytic yeast species have also been reported in some storage tissues (Isaeva et al., 2010). However, this current study seems to be the first report on endophytic yeast isolated from cassava. Yeasts are single-celled fungi belonging to the dikarya subkingdom. They have a wide range of applications such as in food and chemical industries, medicine and agriculture. Yeasts have important roles in agriculture as agents of biocontrol, bioremediation, and as indicators of environmental quality (Türker, 2014). Botryosphaeria are typically opportunistic pathogens which only cause disease in plants when they are stressed, it is known as the causal agent of dieback and cankers in plants (Bush, 2015). Türker Colletotrichum is commonly known to be the causal agent of anthracnose diseases in plants. Nevertheless, some species have shown great potentials as biological control agents and most species are hemi-biotrophic (Jayawardena et al., 2016). Rhizopus sp. was the test pathogen isolated from diseased cassava in this study. It has been reported to be the causal agent of bread molds and soft rot of fruits and vegetables (Agrios, 2015). The association of the pathogen with the diseased cassava suggested that it could be responsible for the symptom observed.

The test endophytes were screened for their biocontrol potential against Rhizopus sp. using dual culture and culture filtrate assay. Table 2 showed the effect of endophytes on the mycelia growth of Rhizopus sp. using the dual culture assay. The results showed that there was a significant difference (at 0.05 level of significance) between the mycelia growth of the test pathogen in single and co-culture with yeast isolate for the three days observed. This indicated that the endophytes have inhibitory effect on the test pathogen (Rhizopus sp.) Yeasts have been reported to play important roles in agriculture as agents of biocontrol, bioremediation, and as indicators of environmental quality (Türker, 2014). Therefore, this observation in this current study agrees with previous reports. However, this study seems to be the first report on the inhibitory effect of yeast against Rhizopus sp. The result in Table 3 also showed that Fusarium sp. had no inhibitory effect on the test pathogen using the dual culture assay. At day 3, there was no significant deference in the mycelia growth of the test pathogen in single $\left(5.58^{c} \pm 0.63\right)$ and co-culture $\left(6.80^{c} \pm 0.10\right)$ with Fusarium sp. However, in the work done by Hamzal et al., 2018, six endophytes (Phoma sp., Xylaria sp., Nigrospora oryzae, Fusarium lateritium, Alternaria macrospora, and Pestalotiopsis sp.) isolated from Rhizophora mucronate were screened for their biocontrol potential. In their study, Fusarium lateritium was reported to have percentage inhibition of $61.89 \%$ against the mycelia growth of the soil borne fungus, Fusarium solani (Hamzal et al., 2018). There were significant differences in the mycelia growth of Rhizopus sp. in single and co-culture with Collectotrichum sp. at day2 and 3 (Table 3). This observation agrees with previous studies. Some species of Collectotrichum sp. have been reported to show great potentials as biological control agents (Jayawardena et al., 2016).

The bio-control potential of the test endophytes against Rhizopus sp. using the dual culture assay in terms of percent growth antagonism is shown in Table 3. The results showed that 
Fusarium sp. has no antagonistic property against the test pathogen for the three consecutive days observed. Yeast isolate 1 and 2 (E3 and E4) had the highest value of percentage antagonism for the three consecutive days observed. The highest percentage antagonism (66.80) was recorded at day 2 for yeast isolate 2. Yeasts have been reported to play important roles in agriculture as agents of biocontrol, bioremediation, and as indicators of environmental quality (Türker, 2014). Therefore, this observation in the current study agrees with previous reports. Collectotrichum sp. also showed some level of antagonism with percentage antagonism, 25.00 and 28.77 recorded at day 2 and 3 respectively. (Jayawardena et al., 2016) reported some species of Colletotrichum to have great potentials as biological control agents. Therefore, this observation in the current study agrees with previous reports.

Table 4 shows the effect of endophytes' culture filtrate on the mycelia growth of Rhizopus sp. In this study, culture filtrate of Fusarium sp. gave the lowest mycelia measurement compared to the other endophytes in the three consecutive days. This suggested that it was more effective than the other endophytes' culture filtrate. However, Fusarium sp. did not show any inhibition against the test pathogen using the dual culture assay. This observation suggested that suppression of the test pathogen by the five fungal endophytic culture filtrates may be due to the production of secondary metabolites. Hamzal (2018) reported that the non-volatile compounds produced by the endophytes isolated from Rhizophora mucronate suppressed the pathogen's growth, causing mycelial growth reduction in $F$. solani when compared to the control plates.

The biocontrol potential of endophytes against Rhizopus sp. using culture filtrate assay in terms of percentage antagonism (Table 5) indicated that Botryosphaeria and Collectotrichum spp. showed no inhibition at day 1 . The culture filtrate of the five endophytes showed inhibitory effect on the mycelia growth of Rhizopus sp. at day 2 and 3. This indicated that the endophytes may have produced non-volatile compounds. In comparison with the work done by Hamzal et al., 2018, six endophytes isolated from Rhizophora mucronate were screened for their biocontrol potential; Phoma sp., Xylaria sp., Nigrospora oryzae, Fusarium lateritium, Alternaria macrospora, and Pestalotiopsis sp. The percentage inhibition of the six endophytes in culture filtrate assay were $23.26 \%, 25.07 \%, 2.07 \%, 21.19 \%, 1.29 \%$ and $11.63 \%$ respectively. In their study, the mycelia accumulation was observed and indicated the presence of non-volatile antibiotics in the filtrate. Therefore, it was shown that non-volatile compounds inhibited the growth of the pathogen (Hamzal, et al., 2018).

In table 6, the growths of endophytes in single and dual culture with Rhizopus sp. were compared. This was done in order to suggest possible mechanism(s) underlying the biocontrol potential of the test pathogens. Fusarium sp. in single culture grew better than in dual culture. There were significant differences between the mycelia growth of the endophyte in single and co-culture with pathogen for the three days observed. This may suggest why the test endophyte did not inhibit the growth of Rhizopus sp. using the dual culture assay. But the culture filtrate of Fusarium sp. gave the lowest mycelia growth of the pathogen. This suggested the presence of antimicrobial agents such as antibiotics and secondary metabolites in the culture filtrate of the test endophyte. All other endophytes also showed significant difference with higher growth in their single cultures than in dual culture with the test pathogen except yeast isolate 2 which showed no significant difference between the single and dual culture. This indicated that yeast isolate 2 has the best ability to compete for space and nutrient. Therefore, competition may be suggested as the mechanism underlying the biocontrol potential of yeast isolates 2 using the dual culture assay. However, the mechanism(s) 
of the test fungal endophytes underlying their bio-control potential against the test pathogen (Rhizopus sp.) should be further investigated.

\section{Implication to Research and Practice}

The findings from this study implies that endophytes have great future potential as biological control agents of Rhizopus sp. in cassava.

\section{CONCLUSION}

The findings from this study indicated that the test fungal endophytes have bio-control potential against Rhizopus sp. using the dual culture and culture filtrate assay. The antagonistic properties of the endophytes differ using the dual culture and culture filtrate assay. Fusarium sp. had the highest percentage antagonism using the culture filtrate assay, but no antagonism was reported using the dual culture assay. Suggested mechanisms underlying the bio-control potentials of the test endophytes include competition, production of secondary metabolites and volatile compounds. The future direction to this study is to carryout molecular profiling of the test endophytes and pathogen to determine species specificity. The mechanisms underlying the biocontrol potentials of the test endophytes should be further investigated.

\section{Future Research}

The mechanisms underlying the biocontrol potential of the test endophytes should be further investigated. Molecular profiling of the test endophytes and pathogen should be carried out to determine species specificity.

\section{REFERENCES}

Agrios, G. N. (2005). Plant Pathology. Fifth Edition. Elsevier Academic Press, London, 922 .

Alves, A. A. C. (2002). "Cassava botany and physiology", Chapter 5, In: Hillocks, R.J., Bush, E. A. (2015). Botryosphaeria canker and dieback of trees and shrubs in the landscape. Virginia Cooperative Extension Publication, 450 - 726 (SPES-23).

Ceballos, H. and Cruz, A. (2012). Cassava taxonomy and morphology. In: Ospina, B. and Ceballos, H. (eds.) Cassava in the third millennium: modern production, processing, use, and marketing systems. Centro Internacional de Agricultura Tropical (CIAT), Cali, Colombia, pp. $15-28$.

Desse, G. and Taye, M. (2001). Microbial load and microflora of cassava (Manihot esculenta Crantz) and effect of cassava juice on some food borne pathogens. Journal of Food and technology, 6(1): 21 - 24. DOI: $10.4314 / \mathrm{jfta} . \mathrm{v} 6 \mathrm{i} 1.19279$

Gao, F., Dai, C. and Liu, X. (2010). Mechanisms of fungal endophytes in plant protection against pathogens. African Journal of Microbiology Research, 4(13): 1346 - 1351. 
Hamzah, T., Lee, S., Hidayat, A., Terhem, R., Faridah-Hanum, I. and Mohamed, R. (2018). Diversity and characterization of endophytic fungi isolated from the tropical mangrove species, Rhizophora mucronata, and identification of potential antagonists against the soil-borne fungus, Fusarium solani. Frontiers in Microbiolology, 9:1707 - 17. https://doi.org/10.3389/fmicb.2018.01707

IITA (1990). Cassava in Tropical Africa: A Reference Manual, International Institute of Tropical Agriculture, Ibadan, Nigeria.

Integrated Taxomonic Information System.

Isaeva, O. V., Glushakova, A. M., Garbuz, S. A. Kachalkin, A. and Chernov, I. (2010). Endophytic yeast fungi in plant storage tissues. Biology Bulletin. 37(1): 26 - 34. https://doi.org/10.1134/S1062359010010048

ITIS (2012), ITIS Standard Report Page: Manihot esculenta, Taxonomic Serial No.: 503688, Jayawardena, R. S., Li, X. H., Liu, M., Zhang, W., and Yan, J.Y. (2016). Mycosphere essay 16: Colletotrichum: Biological control, bio-catalyst, secondary metabolites and toxins. Mycosphere. 7(8): 1164 - 1176. Doi 10.5943/mycosphere/si/2c/7

Katoch, M. and Pull, S. (2017). Endophytic fungi associated with Monarda citriodora, an aromatic and medicinal plant and their biocontrol potential. Pharmaceutical Biology, 55(1): 1528 - 1535. doi: 10.1080/13880209.2017.1309054

Kaur, R., Kaur, J. and Singh, R. S. (2010). Non-pathogenic Fusarium as a biological control agent. Plant Pathology Journal. 9(3): 79 - 91. DOI: 10.3923/ppj.2010.79.91

Moore, L. M. (2005). Cassava Manihot esculenta Crantz. USDA NRCS National Data Center. Baton Rouge, Louisiana.

Obiazikwor, O. H. and Shittu, H. O. (2018). Antifungal activity of silver nanoparticles synthesized using Citrus peel extract against fungal phytopathogens isolated from diseased tomato (Solanum lycopersicum L.). ISSUES IN Biological Sciences and Pharmaceutical Research. 6(3): 30 - 38. doi.org/10.15739/ibspr.18.005

Okungbowa, F. I., Shittu, H. O. and Obiazikwor, O. H. (2019). Endophytic bacteria: hidden protective associates of plants against biotic and abiotic stresses. Notulae Scientia Biologicae. 11(2):167-174. DOI: 10.15835/nsb11210423

Schisler, D. A., Janisiewicz, W. J., Boekhout, T. and Kurtzman, C. P. (2011). Agriculturally important yeasts: biological bontrol of field and postharvest diseases using yeast antagonists, and yeasts as pathogens of plants, In: Kurtzman, P. C., Fell, J. W. and Boekhout T. (eds.) The Yeasts, a Taxononic Study, Elsevier Academic Press, Burlington. pp $45-52$.

Stone, J. K., Bacon, C. W., White, J. F. J (2000). An overview of endophytic microbes: endophytism defined. In: Bacon, C.W., White, J.F., Jr. (Eds.), Microbial Endophytes. Marcel Dekker, New York, pp. 3 - 29.

Thresh, J. M., and Bellotti, A. C. (eds.), Cassava: Biology, Production and Utilization, CABI, Wallingford, United Kingdom, pp. $67-89$.

Türker M. (2014). Yeast biotechnology: diversity and applications. Advances in Science and Industrial Productions of Baker's Yeast. Conference: Proceedings of 27th VH Yeast Conference, Istanbul. 26p. 